The New Person's body: drapery \& disclosure in Stalinist monumental sculpture 1937-44

By Pat Simpson

This essay investigates and contextualises Vera Mukhina's approach to the disclosure of the ideal, ideological body of the Soviet New Person in monumental sculpture between 1937 and $1944 .{ }^{1}$ The works focussed on are Industrial Worker and Collective Farm Girl (1937, fig.1), containing two clothed figures, and Corn (1939, fig.2), featuring two semi-nude figures. The starting point of the investigation is an authoritative paper, 'Theme and Image in Monumental Sculpture', delivered by Mukhina at a conference on monumental sculpture staged by the Moscow Union of Soviet Artists (MSSKh) in September $1944 .{ }^{2}$ The article called for new, powerful and elevated ways of celebrating war heroism in monumental sculpture, through the use of allegory and symbolism. As part of this plea for extending the boundaries of Soviet sculpture, Mukhina raised the question 'Is nudity possible in contemporary monuments? ${ }^{3}$ Her own answer was 'Why ever not?' Yet, to raise this question so baldly, in public, seems unprecedented in a context where the nude, as a representation of the ideal national body, was already closely associated with Nazi ideology, encompassing concepts of racism, sexual selectivity and eugenics, as exemplified by the works decorating the German pavilion at the 1937 Paris exhibition (Fig.7). ${ }^{4}$ 
The first section of this article looks at how Mukhina constructed her definition of the role of drapery/clothing in relation to demonstrably acceptable precedents and precepts in Socialist Realism and European theorisations of classical sculpture, in order to leave a logical space for the nude to occupy within symbolic/allegorical forms of sculpture, such as Corn. The second section notes explicit critical support for Mukhina's ideas, and the generally optimistic atmosphere of the period regarding the extension of Socialist Realist practices. It looks at the potential for the advocacy of the nude, especially by Mukhina, to be perceived as potentially fascist, in particular by its implicit relationship to Soviet discourse on nudism, the body, sexuality and left-wing eugenics of the 1920s. What emerges from this study, I argue, is a theoretical possibility for Socialist Realism to include the nude, but a corresponding practical impossibility for it to happen in the late 1930s and early 1940 s. This was partly because of the cultural prudery enforced by the Party in that period, but mainly because of possible connotations of fascism. These, I suggest, came not just from the visual parallels that might be made with the emphasis on the nude in Nazi art, but, more crucially from association with Soviet 'biologism' and eugenics of the 1920s, with which Mukhina herself had personal connections.

In raising the question 'Is nudity possible in contemporary monuments?', Mukhina drew attention to the ambivalence of Soviet censors and commissioning bodies towards the nude. Communist Party guidance did not 
explicitly prohibit the nude. Paintings, maquettes and plaster casts representing nude figures, were occasionally shown in exhibitions. Some even won prizes. Corn for example, won a prize at the Industry of Socialism exhibition in 1939, although it was shown in a pavilion in Gorky Park, which was a low status sub-section of the exhibition dedicated to the 'food industry'. ${ }^{5}$ Contradictorily, Soviet nudes were not usually permanently installed in public spaces. ${ }^{6} \mathrm{~A}$ notable exception to this general rule, the installation of I. D. Shadr's Girl with an Oar, 1936, in Moscow's Gorky Park, had created much controversy. ${ }^{7}$ Nude and semi-nude neo-classical and replica classical statues were, however, available to the public view in the Park of Culture and in museums. ${ }^{8}$ Moreover, Soviet art education was grounded in academic traditions, in which the focal element was the life-class, with its emphasis on musculature and structure derived from European theories of classical sculpture. It was these traditions and theories, framed in relation to the principles of Socialist Realism, that Mukhina drew on, firstly to define the proper role of drapery in monumental sculpture, and then to identify where drapery might be dispensed with.

Mukhina's argument assumed that monumental sculpture was figurative, and that its primary function was to represent the New Soviet Person. ${ }^{9}$ In doing so, she followed the principles laid down at the first Writers' Union Congress in 1934, that the central educational function of Socialist Realism was to provide images of a future, transformed Soviet humanity in a believable, 
legible form. The New Person, while implicitly acknowledged to be both male and female, was, from 1934 onwards, understood to be a gender-neutral construct of moral and political rectitude and physiological health and beauty, to be advanced as an aspirational model for the Soviet people. Within each cultural product, the 'theme', viewed in the light of current Party concerns, dictated the sorts of class or occupational 'types' to be heroically represented. ${ }^{10}$ Thus, the 'theme' given in Boris lofan's brief for the Paris exhibition pavilion of 1937 - to express the dynamic and progressive nature of the USSR - dictated the representation of the most fundamental class types. ${ }^{11}$ Hence the subject matter of Mukhina's sculpture for the pavilion (Fig.1) was the proletarian and the peasant collective farmer, appropriately gendered to signify on one hand the equality of the sexes proclaimed in the 1936 Constitution, and on the other hand, the pecking order of the two classes in Stalinist ideology. ${ }^{12}$

In 'Theme and Image in Monumental Sculpture', Mukhina's argument, in effect, followed a concern about the translation of 'types' into 'images' within monumental sculpture, expressed in 1924 by A. A. Sidorov in relation to Lenin's 1918 Campaign for Monumental Propaganda. Mukhina, who had participated in that campaign, ${ }^{13}$ took the argument further, asserting that in order to create truly monumental sculpture, the 'type' needed further 'idealisation' to transform it into an 'image', a term which she used to mean something that was both ideologically clear and emotionally powerful. For 
Mukhina, looking back at a selective canon of European sculpture, this was where the 'colossal' role of drapery lay. On the one hand, it could be a means to simplify and idealise the figure into an architectural component, a column, as in the ancient Greek model of the Delphic Charioteer (Fig.3) or the Gothic statues on the portals of Chartres Cathedral (Fig.4). ${ }^{14}$ On the other hand, drapery could be used 'plastically' to create dynamic 'rhythms', as in the Apollo Musagetes (Fig.5), Bernini's St Theresa (Fig.6), or Mickiewicz (1908) by Antoine Bourdelle (Fig.7), in order to amplify the gesture, reinforce the formal dynamics of the composition and enhance its relationship to its destined architectural setting. ${ }^{15}$

The second option was closer to Mukhina's own sculptural preferences and it is possible to see some of these ideas at work in the Industrial Worker and Collective Farm Girl (Fig.1), where the stylised clothing of both figures obliterates certain bodily features, particularly nipples, while accenting the movement of selective aspects of muscularity. Meanwhile the sweep of the scarf iterates the dynamic forward movement while providing another horizontal to complement the angular steps of lofan's building, and balance the vertical of the upraised hammer and sickle. When questioned on the necessity of the scarf by V.M. Molotov, the President of the Soviet government commission to the exhibition, Mukhina apparently replied: 'It is needed for balance'. ${ }^{16}$ Molotov, understanding this in an engineering sense was satisfied, but it is possible that, as her most recent biographer N. V. 
Voronov has suggested, she also meant the statement in formal terms, which, given the post-1934 antipathy to 'formalism' might not have been so well received by Molotov. ${ }^{17}$

Mukhina's articulation of her formal concerns in 'Theme and image' related particularly to the work of Antoine Bourdelle, with whom she had studied at the Académie de la Grande Chaumière, Paris from 1912 to $1914 .{ }^{18}$ Bourdelle came out of the French Beaux Arts tradition, which, with its emphasis on monumental sculpture as a vehicle for moral, patriotic, and physiological ideals, might be seen as an appropriate potential resource for Soviet Socialist Realism. ${ }^{19}$ Indeed, some of the values Mukhina expressed in her article seem to relate closely to the teachings of Bourdelle, for example, the importance of simplifying detail to create rhythms that would express the abstract concept underlying the sculpture. ${ }^{20}$ For Bourdelle this abstract concept was the 'human spirit', an Idealist construct that can be seen to have roots in Hegel's Aesthetics. ${ }^{21}$ Mukhina, writing in a materialist context where Hegel was regarded ambivalently, ${ }^{22}$ avoids referring to 'spirit', but shows aspects of possible reference to Hegel. One of these, is her repeated use of 'idealisation', ${ }^{23}$ a term also used by Gorky but not common in Socialist Realist critical language. ${ }^{24}$ Another possible reference to Hegel lies in elements of Mukhina's approach to the problems of contemporary clothing. 
Like Hegel, Mukhina drew attention to the absurdity of contemporary dress and its unsuitability for monumental sculpture, both for its distraction from the timelessness of the 'image', and for its propensity to deny the physical contours and mechanical actions of the body. Unlike Hegel, however, Mukhina referred exclusively to male clothing. ${ }^{25}$ While admitting that representations of clothing had some historical, contextualising value, Mukhina asserted that this was a secondary consideration. Clothing was only useful when it offered a sense of history but more importantly, had significant, monumental plastic value that amplified the 'image'. She illustrated her argument with works by two Soviet sculptors who had won first-class Stalin Prizes in 1941, Nikolai Tomskii's, Monument to Kirov $\left(1935\right.$, fig.8) ${ }^{26}$ and V. Bogoliubov's Monument to Ordzhonikidze (c. 1938). ${ }^{27}$ Although defining both of these with apparent approval, as 'images' of the 'leader-Bolshevik', she implied the clothing had a purely historical function.

By contrast, Mukhina referred to Bourdelle's Penelope (Fig.9) to exemplify drapery's proper function in the disclosure of the body, through the 'massive' clothing that reveals the 'mighty swing of the thigh' ${ }^{28}$ To reveal the body, she argued, clothing needed to be treated with a lot of 'plastic tact', in order to render it 'necessary and inseparable' (literally 'un-tear-off-able') from the body.$^{29}$ Clearly, from the evidence of Bourdelle's and, indeed, her own sculpture, it appears that this precept did not apply to the whole figure, but rather to salient highlighted features. There are aspects of The Industrial 
Worker and Collective Farm Girl (Fig.1), for instance, where the represented drapery becomes indistinguishable from, or rather, stands in for, skin, except that it veils the genitalia, as well as deleting the details of nipples and navel.

Such details were of primary interest to Paul Schultze-Naumburg, contemporary German theorist of the Nazi ideal body, ${ }^{30}$ and indeed to the sculptor Jozef Thorak whose work adorned the German pavilion at the Paris exhibition in 1937 (Fig.10). In this sense, Mukhina's sculpture, towering above the Soviet pavilion, offered a clear distinction between Soviet and Nazi constructs of their respective ideals of humanity.

Mukhina's use of drapery in Industrial Worker and Collective Farm Girl seems to take account of Alberti's advice to Renaissance artists both in the 'logic' of arranging drapery to reveal the body as if blown against it by a strong wind, and also in using it to preserve modesty, concealing those parts of the body that were 'unpleasing'. ${ }^{31}$ Hegel, partly on the authority of Winckelmann, had emphatically taken up the latter point, on the particular need to conceal women's 'shame' - that is to say genetalia and breasts - on the grounds that representations of the nude spoke too much of sensuousness and distracted attention from a proper concern with expressions of the 'spirit'. In his view, even representations of nude men should be confined to limited themes such as sport. ${ }^{32}$ 
Such a justification for drapery might seem to fit not only with Mukhina's construct of the elevated, idealised 'image', but also with the extreme prudery and anti-eroticism of contemporary Soviet culture during the mid 1930s and 1940s. Bukharin's vision of a Soviet eroticism, articulated at the 1934 Writers' Union Congress, was not incorporated into Socialist Realism. ${ }^{33}$ On the contrary, Ilf and Petrov humorously documented the increasing censorship of images of women that might be judged erotic or smack of sexuality. Pornography and homosexuality were illegal. Sex was a taboo topic. The leading educationalist Makharenko endorsed the ban on sex education in schools, advising parents to change the subject if children enquired about the mechanics of reproduction. ${ }^{34}$ Even kissing, in the street, on films, or in novels was regarded as dubious. ${ }^{35}$ Meanwhile, representations of the nude in art could only be acknowledged to be in some way legitimate if they could be defined as non-erotic. ${ }^{36}$

Yet, within this framework of taboos there was, nevertheless, a materialist element of body-culture. The Soviet ideal of the New Person invoked a physical materialisation, rather than, as in Hegel's case, an essence. Emphasis on sport and physical culture, integral to Party policy from 1918 onwards, became, within the revised educational, physiological, psychological and evolutionary theories of the late 1930s, a means for Soviet citizens to transform themselves into forerunners and progenitors of the New Person. ${ }^{37}$ Some of this concern with the physiology of the New Person may be 
glimpsed in an approving criticism of Industrial Worker and Collective Farm Girl, published in Iskusstvo (Art) in 1937: 'The working clothing of the young man allows his powerful torso to be presented almost naked; the summer dress fitting closely round the figure of the girl makes the construction of her figure apparent' ${ }^{38}$ Similar approval for the revelation of the body in this sculpture, was expressed by the critic A. Zotov in 1944: 'the body forms and revealing clothing show both the outer physical beauty and also the inner pathos of the image'. ${ }^{39}$

These statements suggest that disclosure through drapery, of an edited, ideal physiology was seemingly both acceptable and praiseworthy, even if there were cultural constraints on elaborating descriptions of the admirable bodily characteristics. It was, perhaps, this public and appreciative criticism in 1937, that may have encouraged Mukhina to take the disclosure of the body further in her design for the sculptural group Corn 1939 (Fig.2).

Corn was one of a series of patriotic and thematic sculptural groups designed for the new Moskvoretsky river bridge, built in 1938 near Red Square as part of Stalin's reconstruction of Moscow. ${ }^{40}$ The sculpture was neither officially commissioned nor installed, ${ }^{41}$ indeed the plinths on the bridge are still empty today. ${ }^{42}$ Corn attempted to introduce the nude into a decorative sculpture with monumental overtones - that is to say, into a work based on the patriotic theme of the fruitfulness of the Soviet Motherland. In 1944 Zotov described it 
most explicitly: 'Mukhina's Corn expresses the inexhaustible powers of life. These young, robust women's bodies are full of the genuine health of spiritual strength'. ${ }^{43}$

The sinuous, apparent softness of surface on the nude torsos has some parallels with Bourdelle's decorative nudes, such as Sélène 1917 (Fig.11) although Mukhina's bodies are more athletically muscular. The plaited hair, the sheaves of corn, the representation of the rough bulky skirt, and the femaleness of the image are all signifiers of peasantness. The bodies are not, however, that of the stout peasant baba represented by Mukhina in 1927 (Fig.12)) and recurrent as a type in Socialist Realist art. Despite Zotov's identification of them as 'women' (zhenshchinyi) ${ }^{44}$ they refer to a different 'type', the young girl-woman with small breasts who, by her proximity to childhood was regarded in official educational and psychological theory as still asexual and therefore not an object of erotic desire. ${ }^{45}$

In 1944, articulating her justification for the possible use of the nude in monumental sculpture, Mukhina asserted in politically correct, masculinised but gender-neutral terms: 'You see, the image is given in man and arises out of his inner richness, in this regard clothes play a historically subsidiary role, provided that they are plastically and compositionally unnecessary'. ${ }^{46}$ This definition of drapery cleverly detached the elevated 'image' of the social 'type' - the content of the sculpture - from the historical signifying role of clothing. It 
effectively relegated drapery to the status of a formal element that made it potentially dispensible, since within Socialist Realism, content must always have priority over formal concerns.

Mukhina identified a place for the nude, not in portrait sculpture, but in symbolic or allegorical sculpture, without detailed attributes, pared down to the body as the carrier of meaning. This idea might seem perilously close to Nazi art practices, as for example discussed by Werner Rittich in $1938,{ }^{47}$ but although, like Rittich, Mukhina drew upon classical models, she also drew attention to the Soviet precedent offered by the sculpture October Revolution (1927, fig.13), by Aleksandr Matveev (1889-1941). ${ }^{48}$ Matveev's plaster model had been awarded a prize by the Council of People's Commissars, SovNarKom, at the exhibition 10 Years of Soviet Power in $1928 .{ }^{49}$ It was held by the Tretiakov Gallery, Moscow, but had not been cast or installed in a public space.$^{50}$ Nevertheless, it served as a possible, still revered, example of the nude used in Soviet monumental sculpture to express a powerful idea the unity and determination of the peasant, the proletarian and the Red Army soldier in the victorious struggle for the Bolshevik revolution.

As Matveev had done in October Revolution, Mukhina preserved modesty in Corn, by the positions of the legs and strategically placed drapery over the genitals. In her paper, however, she departed markedly from Hegel's conclusions on the necessity of drapery, by the simple expedient of omitting 
any reference to sexual or moral aspects of body exposure - which accorded with the non-sexual and non-gendered contemporary discourse on the New Person's body. Her unpublished writings, however, indicate her exasperation with contemporary: 'unhealthy Puritanism - fear of the naked body... Only a person with dirty thoughts might see dirtiness in the beautiful human body' ${ }^{51}$ In these writings she also declared:

'Nudity is the most complete and undisguised perception of the inner aspect and condition of man (David) ${ }^{52}$ Consequently, the apparent tendency among us towards false shame (you cannot dress everyone in trousers) is erroneous. The eradication of stupid thoughts is not cured by their fixation. A healthy attitude to the beautiful body must enter into our Soviet aesthetics' ${ }^{53}$

Zotov's fourteen-page monograph on Mukhina, published in January 1944, while not so openly critical of contemporary prudery, supported Mukhina's unpublished concept of the nude, and boldly attempted to explain the significance of the nude to the sculptor as having: 'inexhaustible artistic possibilities...The human body is for him [the sculptor $]^{54}$ the same as a keyboard instrument for a musician, with the help of which he is able to derive all kinds of melodies' ${ }^{55}$ In addition, his description of Corn implicitly addressed the issue of the moral and sensual by attributing patriotic moral values to the nude bodies. Even so, Corn was not among the five works by Mukhina illustrated in his book. ${ }^{56}$ 
Despite the non-inclusion of Corn in Zotov's 1944 monograph, Mukhina seemed justified in responding 'Why ever not?' to the possibility of inserting the nude into the canon of Soviet sculpture. After all, the monograph had been passed by the Party censors. Zotov himself was a critic working within KPDI, an organisation that was the arbiter of what could and could not be published or exhibited. Zotov, moreover, appeared to be a representative of a critical tendency within KPDI that emerged in 1939, which attacked extremes of photographic likeness, castigated as 'naturalism', and applauded aesthetic qualities, including inclinations towards symbol and allegory. ${ }^{57}$ It was probably a result of this tendency that Corn had won a prize at Industry of Socialism in 1939. It was also probable that the influence of this tendency during the war enabled an 'Autobiography', written by Mukhina for the catalogue of a group exhibition held at the Tretiakov Gallery in August $1943,{ }^{58}$ to lament the noninstallation of Corn on the Moskvoretskii Bridge, suggesting that it would have 'resonated very powerfully'. ${ }^{59}$

In 1944, the accession to the directorship of KPDI of the neo-Stasovite ${ }^{60}$ critic Piotr Sysoev, a hard-line advocate of Russian Realism and descriptive, content-based criticism ${ }^{61}$ potentially marked the end of 'anti-naturalist', aesthetically inclined criticism. In 1945, however, as Cullerne Bown has noted, there was still a buoyant sense of possibility for the parameters of Socialist Realism to be extended. ${ }^{62}$ For instance, the Chairman of MSSKh elected in 1939, the painter Sergei Gerasimov, was an apparent opponent of 
the neo-Stasovite tendency, as indicated by his inclination towards impressionistic technique and concern for aesthetic values. ${ }^{63}$ So too was the Chairman of the orgkomitet of all the artists' unions in the USSR, the painter Aleksandr Gerasimov. ${ }^{64}$ Significantly, perhaps, he also had a commitment to the nude in his impressionistic series Russian Communal Bath (Fig.14), works that were, however, not produced for public consumption. ${ }^{65}$ The fact that Mukhina's paper, after being delivered verbally to the MSSKh conference in September 1944, was then published in Sovetskogo iskusstvo, was yet another indication of the apparent contemporary acceptability of the ideas it contained. ${ }^{66}$ Yet, I suggest, in the deeply patriotic days at the end of the war, the nude, and particularly its advocacy by Mukhina, held connotations of fascism that made it unlikely to be a viable addition to the official discourse of Socialist Realism.

The prudery and silence regarding the body and sexuality, that Mukhina challenged with her question 'Why ever not?', had not always been the Soviet cultural norm. In the 1920s, discourse on the New Person had accumulated connections with nudism, free love, genetics and eugenics. In the early days of the Revolution, public demonstrations by the komsomol $^{67}$ in favour of 'Free Love' and against the traditional family, sometimes included the spectacle of women stripping off their clothing. ${ }^{68}$ Nudity had connotations of revolutionary liberation, not only from pre-Revolutionary constraints on sexuality, but also from other bourgeois values. In Weimar Germany this idea was enshrined 
within the Proletarian Naturist Movement of the German left-wing Worker's Culture Movement, where nudity was associated both with egalitarianism and with the enhancement of proletarian health and strength, through physical exercise in the sunshine. ${ }^{69}$ The komsomol 'Down with Shame' movement, which held nude demonstrations in Moscow in 1922, espoused similar ideas. $^{70}$

Within the German left, the nudist movement was linked to ideas of 'positive eugenics', focussed on selective breeding rather than racism and sterilisations, as another means to strengthen and ennoble the working classes. ${ }^{71}$ In this respect there was a direct connection with Russia, via the activities of N.K. Kol'tsov whose portrait, modelled by Mukhina in 1929 (Fig.15) was noted by Zotov as one of her significant portrait sculptures. ${ }^{72}$ In 1920, under the auspices of the Commissariat of Public Health (NarKomZdrav), Kol'tsov created a Eugenics Section at his Institute of Experimental Biology in Moscow, and founded the Russian Eugenics Society. Kol'tsov's approach to eugenics was Mendelian and favoured Galton's idea of eugenics as a new 'civic religion'. He declared in 1922:

The ideals of socialism are bound up with our earthly life but the dream of creating a perfect order in the relations between people is also a religious idea, for which people will go to their deaths. Eugenics has before it a high ideal which also gives meaning to life and is worthy of sacrifices: the creation through conscious work by many generations, of a human being of a higher 
type, a powerful ruler of nature and creator of life. Eugenics is the religion of the future and it awaits its prophets. ${ }^{73}$

As expressed here, Koltsov's ideas had something in common with the preRevolutionary ideas on 'Godbuilding' favoured by his acquaintances Maxim Gorky and Anatoly Lunacharsky. ${ }^{74}$ During the 1920 s, the crypto-religious nuances tended to drop out of the scientific debates on the New Person. The focal issue was whether this new humanity could only develop from selective breeding, or, as held by Lamarckians, whether characteristics acquired from changes in environment could be inherited ${ }^{75}$ An alternative view, propounded by the Commissar for Public Health N.A. Semashko, was that the New Person would arise purely from changes in the social environment. ${ }^{76}$

Explicit state support of eugenics came to an abrupt halt during the so-called 'cultural revolution' accompanying Stalin's First Five Year Plan 1928-33, in a wave of antipathy to 'biologising', which also precipitated the closure of discourse on sexuality and the body. ${ }^{77}$ There seems to have been a correlation between the shift of official Soviet attitudes to such discourses, and the exclusive appropriation of nudist and eugenics discourse by the German Nazi party during the 1930 s. $^{78}$ In 1930 Kol'tsov came under suspicion as a 'bourgeois specialist' and eugenics was denounced as both 'bourgeois' and 'fascist'. ${ }^{79}$ Eugenics research, never really separate from biology and genetics in Russia, continued under a new name of 'medical 
genetics' until denounced again as 'fascist' in 1938, this time with dire consequences: Levit, a leading geneticist was probably shot in May 1938. Kol'tsov, beaten by Lysenko in an election to the Academy of Sciences in 1938, was denounced for his 'fascist' beliefs of the 1920s, and being unwise enough to admit no change in his views, was dismissed from his Institute to die, conveniently, of a heart attack in $1940 .{ }^{80}$

Mukhina had a personal connection with this history. Kol'tsov was a friend of her family. Her husband, the physician A.A. Zamkov worked at Kol'tsov's Institute in the late 1920s, where he became famous for researching the 'therapeutic effects on the human organism of injections of urine from pregnant women' resulting in an endocrine-based wonder-drug 'Gravidan' ${ }^{81}$ Zamkov was denounced in 1930 for 'charlatanism' and sent into exile in Voronezh after he and his family, including Mukhina, attempted to leave the country illegally. After an intervention by Gorky he was allowed back to Moscow in 1933 to work at the Institute of Gravidan Therapy until again denounced in 1938, losing his job and suffering a heart attack. He died in 1942.

Zamkov's work related to eugenics only tenuously, in the sense that he studied an aspect of the biological process of breeding - pregnancy - and the potential value of its organic/hormonal by-products for improving public health. He was fortunate to be denounced for 'feldsherism', a sort of 
quackery, rather than for 'fascism' ${ }^{82}$ Nevertheless, both in the uncertain days of denunciations and purges of 1938-9 and thereafter, the connections with 'biologism', Zamkov and Kol'tsov had potential to cast a cloud over Mukhina's advocacy of the nude, particularly when the latter connection had been obliquely referred to in Zotov's praise of her portrait bust of 'Academician Kol'tsov' ${ }^{83}$ Certainly, her public and private emphasis on structural and mechanical aspects of the body might be linked with what Clark has called the 'mechanical materialism' of 1920s artistic and scientific discourse on engineering the New Person's body, ${ }^{84}$ which by the beginning of the war had become irrevocably linked to 'fascist' and therefore unpatriotic ideas.

No public denunciations followed the publication of Mukhina's article. She was the very model of patriotism. In 1941, perhaps due to the high status and favourable attention from Stalin gained through the Industrial Worker and Collective Farm Girl, ${ }^{85}$ Mukhina had become a leading voice in the 'Women Against Fascism' movement. After the war she was permitted to travel abroad in 1945 and 1946, making celebratory propaganda speeches to assemblies of women in Paris, the Baltic states, Yugoslavia, Bulgaria and the Balkans. ${ }^{86}$

Nevertheless, it is significant that her sculptural output after 1944 focussed on portrait busts of war heroes rather than monumental war memorials, ${ }^{87}$ and she made no more public statements advocating symbol, allegory or the nude. Indeed in 1945, regarding a monument to Tchaikovsky, Mukhina 
publicly asserted her intention, to make a 'portrait sculpture' and not 'run off into symbol and allegory'. ${ }^{88}$ By August 1946 a new cultural era had begun in which there was no place for symbol, allegory or the nude. The 'Zhdanovshchina', named after Stalin's cultural watchdog, A.A. Zhdanov, which lasted until about 1951, was a period of renewed witch-hunts and purges of the art establishment in the name of 'party-mindedness' (partiinost) and patriotism. It led to the reinstatement of ultra-conservative art practices. ${ }^{89}$ In 1948 Mukhina effectively relinquished her advocacy of the nude, declaring to the newly purged and reconstituted Academy of Arts that: "our era... is a clothed era'. ${ }^{90}$

What this study highlights, at the most general level, is the complicated and contradictory nature of the supposedly monolithic practice of Socialist Realism. Mukhina's advocacy of the nude within the context of the late 1930s and early 1940 s seems both a brave and somewhat politically naïve attempt to expand the field of Socialist Realism in the direction of symbol and allegory. There was a certain logic in assuming a place for the nude within an academic practice that was orientated towards classical and neo-classical models, and was based upon the life-room. Mukhina's concern with disclosing the ideal body may also be seen to connect continuing materialistic, socio-political concerns with the physiological engineering of the New Person. In principle, the nude was a means to disclose this ideal body, particularly when the ostensibly 'colossal' role of drapery was reduced to a 
matter of formal consideration. In practice, particularly in the late 1930s, it was impossible. It clashed with the increasing prudery enforced by the Party in the Soviet culture of the 1930s. More importantly it held connotations of fascism, not just in relation to Nazi art, but also with regard to the Soviet eugenics of the 1920s with which Mukhina had had tenuous, but potentially dangerous personal connections.

\section{9 words}

The research on which this article is based was supported by AHRB Small Grants in the Creative and Performing Arts 2002-03, 2004-05.

${ }^{1}$ Vera Ignat'evna Mukhina (1889-1953), Soviet sculptor.

${ }^{2}$ Published:V. I. Mukhina, 'Tema i obraz v monumental'noi skul'pture', Sovetskoe iskusstvo, 2, 14 November, 1944, p.2.

${ }^{3}$ Ibid.

${ }^{4}$ A. Richardson, 'The nazification of women in art', in B. Taylor \& W. van der Will (eds), The Nazification of Art. Art, Design, Music, Architecture and Film in the Third Reich, Winchester, 1990, pp.62-79.

${ }^{5}$ S.E. Reid, "Socialist Realism in the stalinist terror: The Industry of Socialism Art Exhibition 1935-41", The Russian Review, 60, April 2001, pp.174-5, 178184. 
${ }^{6} \mathrm{~V}$. Mukhina, 'O nagote' ('On nudity'), unpublished and undated fragments, in P.B. Klimov (ed.), V.I. Mukhina. Khudozhestvennoe i literaturno-kriticheskoe nasledie, Moscow and Leningrad, 1960, vol.1, p.190.

${ }^{7}$ Ivan Dmitrievich Shadr (1887-1941), Soviet sculptor who studied with Antoine Bourdelle at the Académie de la Grande Chaumière, Paris, 19101911. The sculpture no longer exists. M. Zolotonosov, Kabinet. Glytokratos. Ussledovanie nemogo diskursa. Anotirovanny catalog sadovo-parkhovoi skul'ptury stalinskogo vremeni, St Petersburg, 1999, pp.23-26; M. Zolotonosov, 'Filosofiia obshego tela. Sovetskaia sadovo-parkovskoi skul'ptura 1930-kh godov', in Kharmizdat predstavliaet sovetskii eros 20-30kh godov. Sbornik materialov, St Petersburg, 1997, pp.38-40.

${ }^{8}$ M. Zolotonosov, 'Filosofiia obshego tela.' as at note 7, p.33; Mukhina, as at note 6, p.190.

${ }^{9}$ Mukhina, as at note 2. Her commitment to representing the New Person was stated explicitly in V. Mukhina, ('I want to show the new person in my work', Sovietland, 6, 1936), 'la khochy pokazat' v moikh rabotakh novogo cheloveka', in P.B. Klimov (ed.), V.I. Mukhina. Khudozhestvennoe i literaturno-kriticheskoe nasledie, Moscow and Leningrad, 1960, vol.1, pp.1345.

${ }^{10} \mathrm{P}$. Simpson, 'On the margins of discourse? Visions of New Socialist Woman in Soviet art 1949-50', Art History, XXI, 2, June 1998, pp.250-51. ${ }^{11}$ Brief for the Soviet pavilion in Paris, 10 September 1935 in Jean Louis Cohen, Paris 1937 Cinquantenaire, Paris, 1987, p.184, cited by S. Wilson, 
'The Soviet pavilion in Paris', in M. Cullerne Bown and B. Taylor (eds), Art of the Soviets. Painting, Sculpture and Architecture in a One-party State, 19171992, Manchester \& New York, 1993, p.111.

${ }^{12}$ Simpson, as at note 10, pp.258-9.

${ }^{13}$ A. A. Sidorov, 'Lenin v izobrazitel'noi iskusstve', in N.A. Semashko (ed.), Velikii vozhd, Moscow, 1924, p.203.

${ }^{14}$ Mukhina, as at note 2.

${ }^{15}$ Ibid.

${ }^{16}$ N. V. Voronov, Vera Mukhina, Moscow, 1990, p.156

${ }^{17}$ Ibid.; M. Cullerne Bown, Art Under Stalin, Oxford, 1991, pp.128-9.

${ }^{18}$ M. N. Yablonskaya, Women artists of Russia's New Age 1900-1935, London, 1990, p.221.

${ }^{19}$ A. E. Elsen (ed.) Pioneers of Modern Sculpture (exh. cat.), Hayward Gallery, Arts Council, London, 1975, p.8-9, 118.

${ }^{20}$ C. Giedion-Welcker, Contemporary Sculpture. An Evolution in time and Space, London, (1956) revised and enlarged edition 1961, pp.28, 325.

${ }^{21}$ See for example G.W.F. Hegel, Aesthetics. Lectures on Fine Art, Oxford, 1975, 2 vols, vol.I, p.167; vol.II, pp.710, 717-18, 729, 744.

${ }^{22}$ The Soviet attitude towards Hegel was ambivalent, although he seems to have been regarded as valuable for influencing Marx to adopt a dialectical method, he was also criticised as a bourgeois Idealist for the transcendentalism of his own formulation of the dialectic of history. M. 
Lifshitz, The Philosophy of Art of Karl Marx, 1933, tr. R.B. Winn, (Critics

Group, New York, 1938), London, 1973, pp.19, 21-36.

${ }^{23}$ See Hegel, as at note 21, vol.II, p.748.

${ }^{24}$ See for example M. Gorky, Interview in Iskusstvo, 20 July 1933 cited in Voronov as at note 16, p.52. On p.39, Voronov also makes the connection with Gorky’s construct of 'idealisation'.

${ }^{25}$ Mukhina, as at note 2; Hegel, as at note 21, vol.I, pp.165-6, vol.II, p.746; G. Doy, Drapery. Classicism and barbarism in Visual Culture, London and New York, 2002, pp.22, 29.

${ }^{26}$ S.M. Kirov, member of the Politburo, Party Secretariat and Orgburo, died in 1934. Tomskii won the competition for the monument in 1935, but the statue was cast and installed in 1938. O. Sopotsinsky (ed.), Art in The Soviet Union. Painting, Sculpture and Graphic Arts, Leningrad, (1977) 1978, pp.483-4.

${ }^{27}$ G.K. Ordzhonikidze, Commissar for Heavy Industry, died in February 1937 which makes it likely that the sculpture design was done in 1938 or between 1938-40. See also G. Hosking, A History of the Soviet Union 1917-1991, London, (1985) final edition 1992, p.193; I. Golomstock, Totalitarian Art in the Soviet Union, The Third Reich, Fascist Italy and the People's Republic of China, London, 1990, p.223.

${ }^{28}$ Mukhina, as at note 2.

${ }^{29}$ Ibid.

${ }^{30}$ Schulze-Naumburg, Nordische Schonheit, Munich, 1937, discussed by Richardson, as at note 4, pp.65-68. 
${ }^{31}$ Leon Battista Alberti, On Painting (1535-6), tr. J.R. Spencer, New Haven and London, (1956) 1966, pp.76, 81.

${ }^{32}$ Hegel, as at note 21, vol.II, pp.742-749, 757.

${ }^{33}$ N. Bukharin, 'Poetry, Poetics and the Problems of Poetry in the USSR' in H. G. Scott (ed.), Soviet Writers' Congress 1934. The Debate on Socialist Realism and Modernism, London, (1935) 1977, p.255.

${ }^{34}$ M. Stern and A. Stern, Sex in the Soviet Union, tr. M. E. Heine, London, 1981, pp.41, 123, 106-8, 150-51; I. Kon, 'Sexuality and Culture' in I. Kon \& J. Riordan (eds), Sex and Russian Society, London, 1993, pp.23-4.

${ }^{35}$ K. Menhert, The Anatomy of Soviet Man, tr. M. Rosenbaum, London, (1958) 1961, p.40-41; Stern, ibid., p.112.

${ }^{36}$ M. Raikhinshtein, 'Rezenzii', Iskusstvo, 1935, p.143, discussion of E. Yanson-Manizer Discus Thrower, 1935 cited in N. Sobol Levent, Healthy Spirit in a Healthy Body, Frankfurt am Main, 2004, p.106; M. Cullerne Bown, 'Aleksandr Gerasimov', in M. Cullerne Bown \& B. Taylor, as at note 11, p.132. ${ }^{37}$ P. Simpson, 'Soviet superwoman in the land of liberty. Aleksandr Deineka's Razdol'e, 1944' in S. Adams \& A. Greutzner-Robins (eds.), Gendering Landscape Art, Manchester, 2000, pp.87-101. ${ }^{38}$ Iskusstvo, no.4, 1937, p.121 cited in M. Cullerne Bown, Socialist Realist Painting, London \& New Haven, 1998, p.176.

${ }^{39}$ A. Zotov, Mukhina, Vera Ignat'evna. Narodnyi khudozhnik SSSR, Moscow and Leningrad, 12 January, 1944, p.8. 14 pages, 5 illustrations. Edition of 15,000 copies. 
${ }^{40}$ There were apparently six compositions designed by Mukhina for the two plinths on the bridge: Revolution, Socialist Construction, Flame of the Revolution, Hymn of the Internationale, Fertility and Bread: Voronov, as at note 16, pp.180, 187. Despite claims made in 1938 that Mukhina was currently working on the sculptures for the newly completed bridge, there seems to be no evidence in the records of the Committee for Art Affairs (RGALI) that they were commissioned in 1938 and Khleb is always dated 1939: M. Zolotarev, 'Desiat' mostov', Arkhitekurnaia gazeta, 13, 3 March 1938, p.3; Engineer V. M. Vakhurin, 'Arkhitektura novykh mostov moskvy', Stroitel'stvo moskvy, 9-10, 1938, p.13.

${ }^{41}$ An undated fragment of Mukhina's writing notes that the commissioning body, Mossovet, did not even look at the designs so that they could use the budget allocated to sculpture for the construction of the bridge. P. B. Klimov, (ed.), V.I. Mukhina. Khudozhestvennoe i literaturno-kriticheskoe nasledie, Moscow and Leningrad, 1960, vol.1, p.104.

${ }^{42}$ The bronze version in the collection of the Tretiakov Gallery Moscow was cast during Khruschev's 'Thaw' in 1958, five years after Mukhina's death and given to the gallery by Mukhina's family. Voronov, as at note 16, p.187.

${ }^{43}$ Zotov, as at note 39, p.10.

${ }^{44}$ Ibid.

${ }^{45}$ V. N. Kolbanovskii, 'The sex upbringing of the rising generation', Soviet Education, 1, September 1964, p.9.

${ }^{46}$ Mukhina, as at note 2. 
${ }^{47}$ W. Rittich, 'Architekturgebundene oder freie Plastik?' Die Kunst im Dritten Reich, August 1938, pp.251-257.

${ }^{48}$ Matveev had joined the Party in 1940, but was denounced as an 'impressionist' in the witch-hunts of 1948. Cullerne Bown, as at note 17, p.214.

${ }^{49}$ X. Antonova (ed.), The Tretyakov Gallery Moscow. Painting, Graphic Art, Sculpture, Leningrad, 1983, p.440, ill. p.370. Mukhina's Peasant Woman (1927-28), won a first prize at the same exhibition.

${ }^{50}$ It was finally cast and installed outside the Oktiabrsky concert hall, Ligovskii Street, Leningrad in 1968, and is still there. Sopotsinsky, as at note 26, p.440. Leningrad reverted to its former name of St. Petersburg after the fall of the USSR in 1991.

${ }^{51}$ Mukhina, as at note 6, p.190.

${ }^{52}$ This is a reference to Michelangelo's David.

${ }^{53}$ Mukhina, as at note 6, p. 190.

${ }^{54}$ Even where artists under discussion in Soviet texts were female, the linguistic convention was to treat them as if they were male.

${ }^{55}$ Zotov, as at note 39, p.10.

${ }^{56}$ The works illustrated were: Industrial Worker and Collective Farm Girl (1937); design for a monument to Gorky (1938); Partisan Girl (1942); and two portrait busts of war heroes, Colonels B. A Khizhniak (1942) and I. A lusupov (1942). Mukhina won a Stalin Prize for these busts in 1943. Vera Ignat'evna Mukhina 1889-1953. Skulptura. Dekorativno-prikladnoe iskusstvo. Grafika. 
Teatr. Vystavka proizvedenii k 100-letiiu co dnia rozhdeniia (exh, cat.), Tretiakov Gallery and State Russian Museum, Moscow, 1989, p.28.

${ }^{57}$ A. Zotov, "Proekty stat'i Zotova 'Khudozhestvennaia vystavka industrii sotsializma”, Moscow, RGALI, f.962, op.6, ed.khr 624; I. Grigor'ev, 'Industriia sotsializma', Pravda, 19 March 1939, p.11; S.E. Reid, as at note 5, pp.174-5, $178-184$

${ }^{58}$ The other artists involved in the exhibition were Aleksandr Deineka, Dementii Shmarinov, Sarra Lebedeva, and Piotr Konchalovskii.

${ }^{59}$ V. Mukhina, 'Avtobiografiia', August 1943, in P.B. Klimov (ed.), V.I.

Mukhina. Khudozhestvennoe i literaturno-kriticheskoe nasledie, Moscow and Leningrad, 1960, vol.1, p.9, n.1 p.216.

${ }^{60}$ V. V. Stasov (1824-1906) art critic and supporter of the Peredvizhniki (Itinerants) group of Russian Realists, was concerned with the creation of a nationalistic Russian tradition of art that was descriptive of common people's lives, and engaged with a mode of criticism that focused on content above form. This was taken up by P. Sysoev and a number of other Soviet critics connected with the journal New World (Novyi mir) in the 1930s. E. Valkenier, Russian Realist Art. The State and Society: The Peredvizhniki and Their Tradition, New York, 1989, pp.56-7, 170-171.

${ }^{61}$ Cullerne Bown, as at note 38, pp.187-8, 226.

${ }^{62}$ Ibid., p.223; Cullerne Bown, as at note 17, p.162.

${ }^{63}$ Cullerne Bown, as at note 17, p.134. 
${ }^{64}$ Aleksandr Gerasimov was not related to Sergei Gerasimov, but had been Chairman of MSSKh up to 1939. Ibid.

${ }^{65}$ Cullerne Bown, as at note 38, p.226; Cullerne Bown, 'Aleksandr

Gerasimov', in M. Cullerne Bown \& B. Taylor, as at note 11, p.132.

${ }^{66}$ Sovetskogo iskusstvo was the sole and authoritative arts publication in the USSR during the war, published by MSSKh under the aegis of KPDI.

${ }^{67}$ Young Communist League.

${ }^{68}$ Stern, as at note 34, pp.23-5.

${ }^{69} \mathrm{~W}$. van der Will, 'The body and the body politic as symptom and metaphor in the transition of German culture to National Socialism', in Taylor and van der Will, as at note 4, pp.31-4.

${ }^{70}$ R. Stites, Revolutionary Dreams. Utopian Vision and Experimental Life in the Russian Revolution, Oxford and New York, 1989, p.133.

${ }^{71}$ van der Will, as at note 4, p.34.

${ }^{72}$ Zotov, as at note 39, p.11.

${ }^{73}$ N.K. Kol'tsov, 'Uluchshennie chelovecheskoi porody', Russkii evgenicheskii zhurnal, 1, 1922, pp.3-27.

${ }^{74}$ M. B. Adams, 'Eugenics in Russia', in M.B. Adams (ed.), The Wellborn Science. Eugenics in Germany, France Brazil and Russia, Oxford and New York, 1990, p.162; Cullerne Bown, as at note 38, pp.33, 25.

${ }^{75}$ D. Joravsky, 'Soviet Marxism and biology before Lysenko', Journal of the History of Ideas, XX, 1, January 1959, pp.85-104. 
${ }^{76}$ S. Gross Solomon, 'Social hygiene and Soviet public health 1921-1930', in

S. Gross Solomon and J. F. Hutchinson (eds.), Health and Society in

Revolutionary Russia, Bloomington and Indianapolis, 1990, pp.177-9.

${ }^{77}$ Kon, as at note 34, p.23.

${ }^{78}$ van der Will, as at note 4, p.43.

${ }^{79}$ M. B. Adams, 'Eugenics as a social medicine in revolutionary Russia', in Gross Solomon and Hutchinson, as at note 76, pp.218-19.

${ }^{80}$ Adams, as at note 74, pp.191, 196-8; M.B. Adams, 'The Soviet naturenurture debate', in L. R. Graham (ed.), Science and the Soviet Social Order, Cambridge Mass. and London, 1990, pp.103, 105-7.

${ }^{81}$ Voronov, as at note 16, p.35.

82 Ibid., pp.36, 43.

${ }^{83}$ Zotov, as at note 39, p.11. .

${ }^{84}$ T. Clark, 'The "new man's" body: a motif in early Soviet culture', in Cullerne Bown \& Taylor, as at note 11,p.45.

${ }^{85}$ Voronov, as at note 16, p. 42.

${ }^{86}$ Ibid., p.57.

87 lbid., p.56.

${ }^{88} \mathrm{~V}$. Mukhina, 'Moia rabota $v$ dni voiny', article written for the Vsesoiuznogo obshchestva kul'turnoi sviazi s zagranitsei (All-Union society for links with abroad), 1945, in in P.B. Klimov (ed.) V.I. Mukhina. Khudozhestvennoe $i$ literaturno-kriticheskoe nasledie, Moscow and Leningrad, 1960, vol.1, p.137. 
${ }^{89}$ Cullerne Bown, as at note 17, pp.173, 206; Cullerne Bown, as at note 39, pp.214, 216.

${ }^{90}$ V. Mukhina, 'Vystuplenie na konferentsii posviashchennoi

khudozhestvennomu vospitaniiu i obrazovaniiu', Academy of Arts USSR, 8

May, 1948, in P.B. Klimov (ed.), V.I. Mukhina. Khudozhestvennoe i

literaturno-kriticheskoe nasledie, Moscow and Leningrad, 1960, vol.1, p.36.

\section{List of Illustrations}

1 Vera Mukhina, Industrial Worker and Collective Farm Girl, 1937, stainless steel, h: 24m. Exhibition of Agricultural Achievement Moscow (photo: Novosti Photo Library, London).

2 Vera Mukhina, Corn, 1939, bronze (cast 1958), $164 \times 158 \times 120 \mathrm{~cm}$. Tretiakov Gallery, Moscow (photo: O. Sopotinsky, Art in the Soviet Union. Painting, Sculpture, Graphic Arts, Aurora, Leningrad, (1977) 1978, plate 97). (C) DACS 2006.

3 Greek School (5 ${ }^{\text {th }}$ century B.C), Delphic Charioteer, c.470 B.C., bronze, no dimensions given. Archaeological Museum, Delphi, Greece (photo: Bridgeman Art Library)

4 French School (12 ${ }^{\text {th }}$ century), Old testament figures from the north embrasure of the central door of the Royal Portal of the West façade, stone, no dimensions given. Chartres Cathedral, Chartres, France (photo: Peter Willi, Bridgeman Art Library) 
5 Roman, Hadrianic era, Apollo Musagetes, $2^{\text {nd }}$ century A.D., marble, no dimensions given. Vatican Collection, Museo Pio-Clementino (photo: Vatican Collection, Museo Pio-Clementino)

6 Lorenzo Giovanni Bernini, The Ecstasy of St Teresa di Avila, 1647-52, marble, h: 3.5m. Cornaro Chapel, Church of Santa Maria della Vittoria, Rome, Italy (photo: Bridgeman Art Library)

7 Antoine Bourdelle, Mickiewicz Monument $1^{\text {st }}$ composition of the whole monument, 1909-10, bronze, h: $141 \mathrm{~cm}$. Paris (photo: Bulloz @ Musée Bourdelle, Paris)

8 Nikolai Tomskii, Monument to S.M. Kirov, 1938 (architect N. Trotskii), bronze and granite, h: 15.5m. Kirov Square, Leningrad/St Petersburg, T. Bezobrazova, N Kutuzova, A. Khalmurin, Monumenty SSSR, Sovetskii khudozhnik, Moscow,1969, plate 35 (photo: SCRSS, London)

9 Antoine Bourdelle, Penelope without a spindle, large version, 1912, bronze, $240 \times 90 \times 67 \mathrm{~cm}$, one of a edition of 10. Paris (photo: Bulloz (C) Musée Bourdelle, Paris) 
10 Jozef Thorak, German Pavilion: Group of figures at the entrance, 1937, bronze, no dimensions given. Paris World Expo, 1937, part of a stereoscopic photograph by Heinrich Hoffmann, from Die Weltausstellung Paris 1937, 100 Raumbild-Aufnahmen von Heinrich Hoffman, Diessen am Ammersee, 1937 (photo: akg-images, London)

11 Antoine Bourdelle, Sélène Recumbent, 1917, bronze, h:86cm. Musée Bourdelle, Paris (photo: Daniel Bodin @ Musée Bourdelle, Paris)

12 Vera Mukhina, Peasant Woman, 1927-8 (cast in 1935), bronze, $190 \mathrm{x}$ 79 x 70cm. Tretiakov Gallery, Moscow (photo:M.N. Yablonskaya, Women Artists of Russia's New Age 1900-1935, tr. A. Panton, Thames \& Hudson, London, 1990, p.228, plate 171). (C) DACS 2006.

13 Aleksandr Matveev, October Revolution, 1927, plaster (cast in bronze 1958), $230 \times 183 \times 114 \mathrm{~cm}$. State Russian Museum, St Petersburg. A.I. Bassekhes, Alekandr Terent'evich Matveev, Sovetskii khudozhnik, Moscow, 1960, no page/plate numbers (photo: SCRSS, London)

14 Aleksandr Gerasimov, Russian Communal Bath (study), 1940s, oil on canvas, $79 \times 86 \mathrm{~cm}$. Ray E. and Susan Johnson Collection (photo: The Museum of Russian Art, Minneapolis, Minnesota, USA) 
15 Vera Mukhina, Portrait of Professor N.K. Koltsov, 1929 (cast 1929) bronze, $66 \times 31 \times 36 \mathrm{~cm}$, h. of base $22 \mathrm{~cm}$. Tretiakov Gallery, Moscow (photo: N.V. Voronov, Vera Mukhina, Izobrazitel'noe iskusstvo, Moscow, 1989, p.265). (c) DACS 2006. 